\title{
What Can the Insurance Distribution Directive "Offer" the South African Microinsurance Model?
}

\author{
Samantha Huneberg
}

\section{Introduction}

The European Union (EU) has recently introduced the Insurance Distribution Directive (IDD) ${ }^{1}$ which replaces the previous Insurance Mediation Directive. ${ }^{2}$ This new directive will regulate how insurers and firms design as well as market various insurance products in the EU. ${ }^{3}$ This new directive is aimed at enhancing consumer protection when purchasing insurance products within the EU market. ${ }^{4}$ The IDD is expected to be beneficial to consumers in the insurance market, as consumer protection is the main theme throughout the directive.

Similarly, South Africa has provisions in the Policyholder Protection Rules ${ }^{5}$ (PPRs) specifically aimed at regulating the product design of insurance products. ${ }^{6}$ The newly amended PPRs ${ }^{7}$ contain rules on the product design of both life and non-life insurance ${ }^{8}$ products as well as new provisions on microinsurance. ${ }^{9}$

\footnotetext{
${ }^{1}$ Directive (EU) 2016/97 of the European Parliament and of the Council of 20 January 2016. ${ }^{2}(2002 / 92 /$ EC).

${ }^{3}$ See the purpose of the directive.

${ }^{4}$ There is a very strong emphasis on treating consumers fairly despite the distribution channels chosen to purchase the product.

${ }^{5}$ As promulgated in terms of section 55 of the Short-term Insurance Act 53 of 1998.

${ }^{6}$ See rule 2 of the 2018 PPRs.

${ }^{7}$ Of 2018. As amended in terms of GN 996 in $G G 41928$ of 28 September 2018.

${ }^{8}$ In chapter 3 , rule 2 . This chapter will only consider the microinsurance and product design rules in terms of non-life insurance.
}

${ }^{9}$ Chapter 3, rule 2A of the 2018 PPRs.

\author{
S. Huneberg $(\bowtie)$ \\ University of Johannesburg, Johannesburg, South Africa \\ e-mail: shuneberg@uj.ac.za


It appears as if the trend of consumer protection in insurance is growing internationally. The IDD is to have far-reaching consequences in terms of how insurance products are designed and sold within the various EU markets. As far as the current regulations in South Africa are concerned, the newly amended PPRs are also strongly geared towards consumer protection and this is especially evident with the introduction of the new rules on microinsurance. ${ }^{10}$ Microinsurance is finally recognised as a formal type of insurance product within the South African market and this is to have widespread consequences for a large portion of the South African market.

Microinsurance is known as insurance with lower premiums and therefore also lower coverage. ${ }^{11}$ Microinsurance refers to insurance products that provide coverage to low-income earners and households (this would be considered the mass market in South Africa). ${ }^{12}$ A microinsurance policy therefore provides protection to individuals who generally have little savings. ${ }^{13}$ These types of insurance policies are now managed in accordance with generally accepted insurance practices in South Africa. ${ }^{14}$

The fact that microinsurance has now been identified as a formal insurance product in South Africa is laudable due to the fact that the country's population consists of a large number of low-income earners. Insurance policies are renowned for being cumbersome, generally one-sided in favour of the insurer, and can be difficult to understand for the layman. This means that many vulnerable and financially illiterate consumers are being take advantage of by unscrupulous insurers. The newly amended PPRs are aiming to regulate microinsurance as well as provide concrete rules on the product design of insurance products in order to promote these products to a larger portion of the population. These provisions are therefore seeking to protect policyholders from insurers. ${ }^{15}$

However, the question arises whether the current rules on microinsurance in South Africa are indeed realistic and within reach, in light of the consequences facing these consumers? Can more be done in order to provide better coverage of microinsurance products to these specific consumers? This chapter seeks to answer these questions by analysing certain provisions of the IDD and ultimately asking whether the South African microinsurance model can learn or take away something of value from the provisions of the IDD? It was mentioned above that the IDD is specifically aimed at regulating how insurers design and sell products to the EU market and therefore, the provisions may be of value to the South African model of

\footnotetext{
${ }^{10}$ See rule $2 \mathrm{~A}$ of the 2018 PPRs.

${ }^{11}$ Hunt (2019) What is Microinsurance? The Balance https://www.thebalance.com/what-ismicroinsurance-4165961. Accessed 13 July 2019.

${ }^{12}$ Millard (2012), p. 665.

${ }^{13}$ See the National Treasury's Policy Document on the South African microinsurance regulatory framework July 2011.

${ }^{14}$ See rule $2 \mathrm{~A}$ of the 2018 PPRs.

${ }^{15}$ See chapter 2 , rule 1 of the 2018 PPRs which deals with the fair treatment of policyholders.
} 
microinsurance, which should ultimately aim at inclusivity and consumer protection for these particular consumers.

\section{The Insurance Distribution Directive}

\subsection{Introduction}

As was mentioned in paragraph 1 above, the IDD was introduced in the EU market in January 2016. ${ }^{16}$ This directive replaces the previous Insurance Mediation Directive. ${ }^{17}$ The IDD focuses strongly on the concept of 'insurance distribution'. This concept refers to the selling, the proposed selling, advice on or preparing in any way, the conclusion of an insurance contract. ${ }^{18}$ The IDD is strongly geared towards the fair treatment of all policyholders and the Recital specifically states in paragraph 6 that,

Consumers should benefit from the same level of protection despite the differences between distribution channels. In order to guarantee that the same level of protection applies and that the consumer can benefit from comparable standards, in particular in the area of the disclosure of information, a level playing field between distributors is essential. ${ }^{19}$

From the above, it is evident that the IDD is focuses strongly on the various distribution channels through which insurance is sold to policyholders, therefore ensuring that policyholders are treated equally whether purchasing insurance through an intermediary, broker or other operators. ${ }^{20}$ The Directive mentions that a level playing field should be achieved through the implementation of the provisions of the IDD. ${ }^{21}$

The purpose of the IDD is for consumers to ultimately benefit from its provisions through improved sales standards ${ }^{22}$ and the extension of those standards to new areas of protection. ${ }^{23}$ Before specific provisions of the Directive will be considered, it is necessary to consider the scope of application of the Directive. For purposes of

\footnotetext{
${ }^{16}$ Directive (EU) 2016/97.

${ }^{17}$ (2002/92/EC).

${ }^{18} \mathrm{EU}$ Rules of Insurance Distribution https://ec.europa.eu/info/business-economy-euro/bankingand-finance/insurance-and-pensions/insurance-distribution_en. Accessed 13 July 2019. See also Chapter 1, Article 2 of the IDD for the full definition.

${ }^{19}$ See paragraph 6 of the 2016/97 Directive (EU).

${ }^{20}$ Interestingly, the directive covers travel agents, car rental companies, and 'bancassurance' operators. See paragraph 5 of the Recital to the directive. The IDD therefore regulates the activities of insurance intermediaries, insurance companies, their employees, ancillary insurance intermediaries as well as online distribution. Evidently, the directive will have a greater impact in terms of the distribution channels than its previous counterpart. See also paragraph 7 and 8 of the Directive.

${ }^{21}$ Paragraphs 6 and 16.

${ }^{22}$ Paragraph 6.

${ }^{23}$ For example, to insurance-based investment products.
} 
this chapter, only specific sections of the IDD will be considered which are relevant to the comparison with microinsurance provisions in South Africa.

\subsection{Scope of Application}

Chapter 1, article 1 of the Directive sets out the scope of application. The previous Insurance Mediation Directive applied to the regulation of insurance intermediaries, whereas the IDD now has a much broader application. ${ }^{24}$ This wider application applies to all sellers of insurance products, including insurance undertakings that sell directly to customers; firms who are not insurers and whose activities include advising on, proposing, concluding, carrying out other work prior to the conclusion of a contract of insurance or assisting in the administration and performance of contracts of insurance-intermediaries and lastly, ancillary insurance intermediaries. $^{25}$

It is also necessary to consider those transactions to which the IDD does not apply. Paragraph 13 states that the Directive will not apply "to mere introducing activities consisting of the provision of data and information on potential policyholders to insurance or reinsurance intermediaries or undertakings or of information about insurance or reinsurance products or an insurance or reinsurance intermediary or undertaking to potential policyholders." ${ }^{26}$ It also does not apply "to persons with another professional activity, such as tax experts, accountants or lawyers, who provide advice on insurance cover on an incidental basis in the course of that other professional activity, nor should it apply to the mere provision of information of a general nature on insurance products, provided that the purpose of that activity is not to help the customer conclude or fulfil an insurance or reinsurance contract. This Directive should not apply to the professional management of claims on behalf of an insurance or reinsurance undertaking, nor to the loss adjusting and expert appraisal of claims."27

\footnotetext{
${ }^{24}$ See article 1 (2).

${ }^{25}$ Paragraphs 5 and 8.

${ }^{26}$ Paragraph 13. This exemption has been transposed by HM Treasury into Article 33B of The Financial Services and Markets Act 2000 (Regulated Activities) Order 2001 (RAO). New guidance has been added into the FCA Handbook that Article 33B only will cover "those situations where a person provides existing information they hold on potential policyholders (for example their name and contact details) but does not extend to information they obtain from other means such as pre-purchase questioning". This wording suggests that activities falling under this exemption will be limited in nature and provide only a slight extension to existing exclusions such as the provision of information on an incidental basis (Article 72C RAO) and arrangements enabling parties to communicate (Article 27 RAO).

${ }^{27}$ Paragraph 14.
} 
Worth noting is article 1, paragraph 3 which importantly states that the "Directive shall not apply to ancillary insurance intermediaries carrying out insurance distribution activities where all the following conditions are met:

(a) the insurance is complementary to the good or service supplied by a provider, where such insurance covers:

(i) the risk of breakdown, loss of, or damage to, the good or the non-use of the service supplied by that provider; or

(ii) damage to, or loss of, baggage and other risks linked to travel booked with that provider;

(b) the amount of the premium paid for the insurance product does not exceed EUR 600 calculated on a pro rata annual basis;

(c) by way of derogation from point (b), where the insurance is complementary to a service referred to in point (a) and the duration of that service is equal to, or less than, three months, the amount of the premium paid per person does not exceed EUR 200." 28

The Directive also does not apply to insurance and reinsurance distribution activities located outside the Union. ${ }^{29}$

Whilst the IDD makes no specific mention of the concept of microinsurance, it is not clear whether the directive would in fact apply to microinsurance products as these types of insurance products are not a common feature in the EU. ${ }^{30}$ However, if we apply paragraph 3 of article 1 to microinsurance, then it would appear that the IDD would not be applicable to microinsurance where the insurance is complementary to the goods or services provided by a service provider, as long as the other conditions of paragraph 3 are met. This is based on the fact that there is a cap on the amount of the premium paid in this specific instance. This is a key feature in microinsurance, the premiums paid are set in accordance with the maximum amount of coverage provided in terms of the microinsurance policy.

Therefore, microinsurance products may very well fall within the other areas of scope within the IDD but because these types of insurance products are not a common feature in the market, it is unclear at this stage whether the rules in the IDD would in fact apply to microinsurance products. However, this is not a primary concern of this chapter. Rather, the focus of this chapter is to analyse certain provisions of the IDD relating to the product design of insurance products in general and seek to answer the question of whether any of these provisions can be helpful in the design and selling of microinsurance products in South Africa.

The first relevant provisions of the IDD to consider are the provisions relating to disclosure requirements.

\footnotetext{
${ }^{28}$ Read together with article 1(4).

${ }^{29}$ Article 1(6).

${ }^{30}$ Take note that Belgium has implemented specific legislation on microinsurance.
} 


\subsection{Disclosure Requirements of the IDD}

It is interesting to note that article 17 in chapter 5 of the Directive starts off by stating that "insurance distributors must always act honestly, fairly and professionally in accordance with the best interests of the customer." This already indicates the theme of consumer protection which the Directive seeks to achieve.

The disclosure requirements in terms of the IDD impose a wider range of obligations on insurance firms. ${ }^{31}$ Article 18 sets out general information to be provided by an intermediary or undertaking. The disclosure requirements state that anyone acting as a distributor must confirm whether they are acting as an insurer or an intermediary; ${ }^{32}$ intermediaries must state whether they are acting on behalf of the customer or the insurer; ${ }^{33}$ where intermediaries are contractually obliged to conduct business with one (or, even more) insurers, they are now under a pro-active duty to provide the customer with the name of the insurer; intermediaries must disclose the "nature and basis", or type and origin, of the remuneration that they receive in relation to the contract of insurance in question; ${ }^{34}$ and insurers are required to disclose the "basis" of the remuneration paid to their employees. 35

From the above it is clear that the new disclosure requirements in terms of the IDD require insurance firms and intermediaries to reconsider their current sales scripts and client documentation and to ultimately make considerable amendments where necessary, so that the firms are in line with the current requirements of the IDD. This thus requires all insurance firms selling insurance products to conform to the necessary disclosure requirements and ensure that the way in which they sell insurance products are currently in line with the provisions of the directive. ${ }^{36}$

Now that the disclosure requirements of the IDD have been considered, it is necessary to evaluate the relevant provisions on consumer needs. The reason for this is due to the fact that in microinsurance, the consumers' needs are of the utmost importance when designing these types of insurance products.

\subsection{Consumer Needs}

Under the IDD, all insurance distributors are now required to specify consumers' demands and needs based upon information obtained from them. ${ }^{37}$ They must also ensure that the insurance policy proposed or recommended to the customer is

\footnotetext{
${ }^{31}$ See Paragraph 21.

${ }^{32}$ Paragraph 40.

${ }^{33}$ Article 18(a)(v).

${ }^{34}$ Paragraph 41.

${ }^{35}$ Paragraph 46.

${ }^{36}$ See article 18 and 19.

${ }^{37}$ Paragraph 44. See article 20.
} 
consistent with those demands and needs. ${ }^{38}$ These new obligations will require insurance distributors to be more active when assessing demands and needs with customers prior to the insurance being sold. ${ }^{39}$

In the case where no personal recommendation or advice is being made to the customer (or rather non-advised sales are undertaken), the Directive states that the customer should be given the relevant information about the product to allow the customer to make an informed decision. ${ }^{40}$ This means that a product information document should provide standardised information about non-life insurance products. ${ }^{41}$ Article 20(6) states that the insurance product information document referred to in paragraph 5 shall be drawn up by the manufacturer of the non-life insurance product. $^{42}$ The intermediary should explain the key features of the insurance product as well as the fact that its staff should be given appropriate time and resources to do so. ${ }^{43}$ For example, in the case of a motor insurance policy, the consumer should be informed about the types and levels of cover or excess. ${ }^{44}$ Under article 20(7), all the necessary information required for the insurance product information document is set out. Under this paragraph, it requires these documents to be short, laid out in a clear manner, be written in official languages of Member States, be accurate and not misleading, and include a statement to the effect that complete pre-contractual and contractual information on the product is provided in other documents. ${ }^{45}$ These requirements are all aimed at ensuring that the customer is receiving all the necessary information regarding the insurance product and that they understand exactly what they are entering into.

In the instance where insurance firms provide personal recommendations to customers, this also requires them to provide a personalised explanation of why a particular insurance policy would best meet the customer's demands and needs. ${ }^{46}$ Under article 20(3), it is mentioned that it is essential that customers know whether they are dealing with an intermediary who gives advice on the basis of a fair and personal analysis. ${ }^{47}$ The intermediary must take into account the needs of the customer, the number of providers in the market, the market share of those providers and the number of relevant insurance products available from each provider. ${ }^{48}$ This provision therefore ensures that products are appropriate for specific customers, that

\footnotetext{
${ }^{38}$ Paragraph 45. See article 20(1).

${ }^{39}$ Paragraph 44.

${ }^{40}$ Paragraph 48. See article 20(4).

${ }^{41}$ Paragraph 48. See article 20(5).

${ }^{42}$ See article 20(6).

${ }^{43}$ Paragraph 48 . See article 20(7).

${ }^{44}$ See article 20(8).

${ }^{45}$ See article $20(7)$.

${ }^{46}$ Paragraph 47. See article 20(1)-(3).

${ }^{47}$ See article 20(3).

${ }^{48}$ Paragraph 47 . See article 20(3).
} 
their needs have been taken into account in terms of the entire market and that the best insurance product for their needs is being offered to them.

Article 20, as a whole, aims to ensure that customers' needs are taken into account when selling various insurance products, that customers understand the type of product they are purchasing and that all the necessary information about the product is conveyed to the customer in the form of a product information document. ${ }^{49}$ The fact that this document must be short, ${ }^{50}$ easy to read and written in official languages of the Member States is commendable. ${ }^{51}$ This ensures that customers of all backgrounds, that being whether financially literate or not, should be capable of understanding the contract and its content. This guarantees consumer protection for all, various types of consumers.

Interestingly, on 21 August 2017 a further regulation was implemented which sets out a standardised presentation format for the insurance product information document. The regulation works in conjunction with the IDD and sets out specific standards which must be adhered to by the insurance product manufacturers. The regulation states that the format of the document must contain the manufacturers name and logo. ${ }^{52}$ As far as the length of the document is concerned, it shall be set out on two sides of A4-sized paper when printed. ${ }^{53}$ The format of the document must also be according to a specific order of content as suggested in article 4. The document must also have specific headings as set out in the regulation. ${ }^{54}$ The regulation therefore ensures that all insurance manufacturers are bound by the same set of rules therefore ensuring that the product information document is consistent and standardised throughout. Consumers will therefore be treated equally and receive the same document despite the manufacturer of the product.

Article 23 also states that information provided to the customer must be communicated on paper, in a clear and accurate manner, in an official language and free of charge. This means that customers can obtain all the necessary information on the insurance product in a clear manner. ${ }^{55}$

\footnotetext{
${ }^{49}$ See Commission implementing regulation 2017/1469 on 21 August 2017.

${ }^{50}$ Set out on both sides of an A4 document. See article 3 of the Commission implementing regulation 2017/1469 on 21 August 2017.

${ }^{51}$ See the Commission implementing regulation 2017/1469 on 21 August 2017. Article 5 says that it must be presented in plain language, no jargon may be used.

${ }^{52}$ Article 1.

${ }^{53}$ Article 3.

${ }^{54}$ Article 6.

${ }^{55}$ Take note that the IDD contains specific rules on cross-selling in article 24 . However, crossselling is not of importance when it comes to microinsurance in the South African market and therefore will not be discussed in detail. The provisions on cross-selling state that The IDD states that where the insurance product is the 'primary' product offered in the package, then the distributors must inform customers whether it is possible to purchase each component separately. If this is in fact the case, the customer must be provided with appropriate information on these different components; a description of how the interaction between the different components changes the risk or the insurance coverage, and evidence of separate costs and charges for each component. Where the insurance is the 'ancillary' product, distributors will need to ensure that the
} 


\subsection{Product Oversight and Governance Requirements}

Article 25 of the directive contains provisions relating to a product approval process. The article states that undertakings as well as intermediaries which manufacture insurance products for sale to customers must maintain, operate and review a process for the approval of each product, or even relating to significant adaptations of an existing product, before it is marketed or distributed to customers. ${ }^{56}$

This approval process must specify the target market for each product, identify the risks associated with the product for the target market, and ensure that the intended distribution strategy is consistent for the target market. ${ }^{57}$ Therefore, it is the responsibility of the insurance undertaking or intermediary to take reasonable steps to ensure that the insurance product is distributed according to the target market.

Further, on 21 September 2017, the EU issued the delegated Regulation 2017/ 2358 that deals specifically with product oversight and governance requirements for insurance undertakings and insurance distributors. The regulation sets out rules on product governance issues for both manufacturers and distributors. ${ }^{58}$ Therefore, the regulations contains concise rules on the manufacturing of insurance products, ${ }^{59}$ the product approval process, ${ }^{60}$ the target market, ${ }^{61}$ product testing and monitoring and review processes, ${ }^{62}$ and distribution channels utilised. ${ }^{63}$

This regulation therefore compels both manufacturers as well as distributors to adhere to the specific rules as contained in the regulation. Customers will benefit from this in that they will receive fair treatment and standardised services from both.

The provisions on product oversight are of relevance to microinsurance products as the rules on the target market and the actual product review process will be of major importance when microinsurance products are being sold and marketed to the correct market.

non-insurance elements are available to be purchased by customers on the same terms, but without the insurance.

${ }^{56}$ See article $25(1)$.

${ }^{57}$ See article 5(1) of the Delegated Regulation 2017/2358 of 21 September 2017.

${ }^{58}$ See chapters II and III respectively.

${ }^{59}$ Article 3 of Delegated Regulation $2017 / 2358$ of 21 September 2017.

${ }^{60}$ Article 4.

${ }^{61}$ Article 5.

${ }^{62}$ Article 6 and 7 respectively.

${ }^{63}$ Article 8 . 


\subsection{Pre-Contractual Information}

Under article 20, the manufacturer of a non-life insurance product, such as a motor insurance or home contents policy, is required to draw up a document called the Insurance Product Information Document (IPID), which insurance distributors must provide to the customer prior to the conclusion of the insurance contract.

According to article 20(8), the insurance product information document shall contain information about the type of insurance, a summary of the insurance cover, main risks, sum insured, the means of payment of premiums, main exclusions, obligations at the start of contract, obligations during the term of contract, obligations when a claim is made, the term of the contract and means if terminating the contract.

Worth noting is that this information is given to the customer before the contract is concluded, therefore assisting the customer in making an informed decision. The actual contract is delivered to the customer once they have entered into the contract. Therefore, the pre-contractual document does not replace the actual contract. This is a very beneficial practice for the customer as it provides the customer with a brief and easy to read summary of the product and allows the customer to make an informed decision.

\subsection{Preliminary Remarks}

The above paragraphs considered certain provisions from the IDD which would be of value to the microinsurance market in South Africa. From the above, it is evident that the IDD regulates the way various insurance products are designed and sold either by insurance intermediaries, or directly by insurance undertakings and even through other "ancillary insurance intermediaries". ${ }^{64}$ Clearly, consumer protection is the theme throughout the directive. It sets out the information that should be given to consumers before they sign an insurance contract; ${ }^{65}$ provides customers with a summary of the product before the contract is concluded and therefore allows them to make informed decisions. These features of the IDD can be of use in the South African microinsurance industry as it would allow low-income earners the opportunity to understand the product before purchasing the insurance cover.

\footnotetext{
${ }^{64}$ Paragraph 2.1. highlighted the importance of the various distribution channels in insurance and the whole point of the IDD is to enhance consumer protection despite through whom insurance is bought. See article 18. "Ancillary insurance intermediaries" are businesses offering insurance as an add-on to products and services proposed by them. Typical examples include travel agencies or airlines offering travel insurance or sellers of electrical appliance proposing insurance against theft and damage.

${ }^{65}$ Article 18.
} 
As far as preliminary remarks regarding the Directive are concerned, it is evident that the IDD is aimed at ensuring the all insurance products, despite the chosen distribution channel, must be appropriately designed for each customer by taking into account their needs and that approval processes are carried out at all levels by all distributors in order to ensure that consumer protection is achieved. This will be of major significance to the microinsurance market in South Africa.

With this in mind, it is now necessary to consider the rules in South Africa on microinsurance and then evaluate these rules according to the high standard of the IDD provisions. However, before looking at the rules in South Africa, the concept of microinsurance on an international level will be considered.

\section{The Concept of Microinsurance}

\subsection{Introduction}

Microinsurance may be viewed as a recent or 'new' concept. ${ }^{66}$ Some of the first countries to implement specific regulations on microinsurance are: India, which was the first in 2005, followed by the Philippines in 2006, ${ }^{67}$ Peru in 2007, Mexico in 2008, Taiwan in 2009, and Brazil in 2012. ${ }^{68}$ The concept of microinsurance is aimed at financial inclusivity. ${ }^{69}$ It is trite that insurance is generally taken out by people who can afford it. More affluent consumers are generally in a position to afford insurance. It can be quite costly and this does not allow low income earners the opportunity to afford insurance. This is where microinsurance comes in. Microinsurance is insurance aimed at providing coverage for low-income earners. ${ }^{70}$ These types of earners are especially prevalent in emerging markets where insurance may not be as established as other more developed markets. ${ }^{71}$ Therefore, in order for microinsurance to succeed in emerging markets, it is essential that these policies are specifically designed with the correct target market in mind. Microinsurance products and policies must be designed for a different group from the current, average consumer.

\footnotetext{
${ }^{66}$ In South Africa, microinsurance provisions were only enacted as recently as 2018 . However, the IAIS in its 2007 policy document states that it is fact not a new concept as things like funeral insurance and mutual insurance have existed for a long time.

${ }^{67}$ Philippine Insurance Commission (2010) Regulations for the provisions of microinsurance products and services. Manila, Philippines.

${ }^{68}$ Biener et al. (2013), p. 2.

${ }^{69}$ Biener et al. (2013), p. 2.

${ }^{70}$ The IAIS states in its policy document on microinsurance that low-income earners differ from country to country and is generally based a country's state of development.

${ }^{71}$ For example, in South Africa.
} 
Microinsurance can be defined as "a financial arrangement designed to protect low-income people against specific perils in exchange for regular premium payments proportionate to the likelihood and cost of risk involved". ${ }^{72}$

Microinsurance needs to take the specific interests of its consumer into account when developing the regulation and supervision of these products. ${ }^{73}$ The principles behind microinsurance are to develop specific insurance policies with the aim of enhancing access to financial services for more vulnerable consumers, to create awareness around these financial products for these consumers, promoting education as well as to enact well-defined laws aimed at the financial inclusivity of these low-income earners. ${ }^{74}$ In order for microinsurance to work, these factors need to be taken into account.

\subsection{Microinsurance on an International Level}

International insurance bodies, such as the International Association of Insurance Supervisors (IAIS), have considered the importance of microinsurance. In June 2007, the IAIS published a policy document, Issues in Regulation and Supervision of Microinsurance, aimed at providing a thorough and realistic view on the implementation of microinsurance. ${ }^{75}$ This policy document considers the fundamental issues aimed at enhancing a legal framework for microinsurance on an international level. The document explains the current state of microinsurance which is being developed for the low-income population on the basis of practical and prudent insurance business principles, as well as the importance of its role in developing inclusive financial systems particularly within emerging markets, and lastly, why this type of insurance product needs to be regulated and supervised along professional lines. ${ }^{76}$

\footnotetext{
${ }^{72}$ Churchill and Matul (2007), pp. 1-3.

${ }^{73}$ Churchill and Matul (2007), pp. 1-3.

${ }^{74}$ Churchill and Matul (2007), pp. 1-3.

${ }^{75}$ International Association of Insurance Supervisors and CGAP Working Group on Microinsurance (2007) Issues in Regulation and Supervision of Microinsurance. Available at https://www.google.co.za/url? sa $=t \& r c t=j \& q=\&$ esrc $=s \&$ source $=$ web $\& c d=2 \&$ ved=2ahUKEwihqKiQx_boAhULQhUIHXeACP0QFjABegQIAhAB\&url=https $\% 3 \mathrm{~A} \% 2 \mathrm{~F} \%$ 2 Fwww.iaisweb.org $\% 2$ Ffile $\% 2 \mathrm{~F} 34275 \% 2 \mathrm{Fissues}$-paper-in-regulation-and-supervsion-ofmicroinsurance-june-2007\&usg $=\mathrm{AOvV}$ aw340q60e8yb_D9kNa5i0oEp. Accessed 30 August 2019.

${ }^{76}$ International Association of Insurance Supervisors and CGAP Working Group on Microinsurance (2007) Issues in Regulation and Supervision of Microinsurance. Available at https://www.google.co.za/url? sa $=t \& r c t=j \& q=\&$ esrc $=s \&$ source $=$ web $\& c d=2 \&$ ved=2ahUKEwihqKiQx_boAhULQhUIHXeACP0QFjABegQIAhAB\&url=https\%3A\%2F\% 2Fwww.iaisweb.org\%2Ffile $\% 2 \mathrm{~F} 34275 \% 2 \mathrm{Fissues}$-paper-in-regulation-and-supervsion-ofmicroinsurance-june-2007\&usg=AOvVaw340q60e8yb_D9kNa5i0oEp. Accessed 30 August 2019.
} 
Importantly, the IAIS states that microinsurance is not limited to any type of insurance product or line or service provider. ${ }^{77}$ Therefore, microinsurance can take the form of life or non-life insurance and can be distributed through any of the appropriate channels.

The Institute of Insurance Economics in Switzerland has also emphasised the importance of growing microinsurance and the need for such products in emerging markets. There is still a very large portion of the world that does not have access to insurance products. It is estimated that worldwide, four billion people do not have access to insurance products. ${ }^{78}$ Therefore, the Institute published reports on microinsurance and made recommendations as to how these products can be specifically designed and marketed for the appropriate consumers.

The Regulation in Microinsurance Markets: Principles, Practice, and Directions for Future Development outlines specific features that microinsurance products should encompass. ${ }^{79}$ The paper importantly highlights that insurance policies being sold are increasing yearly. The ILO indicated that the number of policies sold between 2009 and 2012 increased from 135 million to 500 million. $^{80}$ This is a significant increase and indicates the prevalence of the uptake of policies. However, even in light of these numbers, there is still a vast portion of the market worldwide that do not have access to insurance products due to that fact that for most, insurance is a luxury. Microinsurance appears to be the most viable initiative in penetrating this unserved market. ${ }^{81}$ Some of the key features that the paper outlines which are necessary for the development of microinsurance policies are financial literacy, risk management procedures, consumer protection measures and highly effective regulatory frameworks which supports the growth of the microinsurance market. ${ }^{82}$

Consumer protection appears to be at the forefront of the development of this market. ${ }^{83}$ This concept is highlighted by Llanto, in which he states that "any regulatory system around microinsurance products should encourage consumer

\footnotetext{
${ }^{77}$ Ibid at page 5 .

${ }^{78}$ International Association of Insurance Supervisors and CGAP Working Group on Microinsurance (2007) Issues in Regulation and Supervision of Microinsurance. Available at https://www.google.co.za/url?sa=t\&rct=j\&q=\&esrc=s\&source=web \& $\mathrm{d}=2 \&$ ved=2ahUKEwihqKiQx_boAhULQhUIHXeACP0QFjABegQIAhAB\&url=https\%3A\%2F\% 2Fwww.iaisweb.org\%2Ffile\%2F34275\%2Fissues-paper-in-regulation-and-supervsion-ofmicroinsurance-june-2007\&usg =AOvVaw340q60e8yb_D9kNa5i0oEp. Accessed 30 August 2019.

${ }^{79}$ Biener et al. (2013), pp. 2-3.

${ }^{80}$ ILO (2012).

${ }^{81}$ Biener et al. (2013), p. 2.

${ }^{82}$ Biener et al. (2013), pp. 2-5.

${ }^{83}$ The IAIS mention in their policy document that consumer protection is vital to the proper implementation of such policies. See page 6 of the International Association of Insurance Supervisors and CGAP Working Group on Microinsurance (2007) Issues in Regulation and Supervision of Microinsurance. Available at https://www.google.co.za/url $? \mathrm{sa}=\mathrm{t} \& \mathrm{rct}=\mathrm{j} \& \mathrm{q}=\& \mathrm{esrc}=\mathrm{s} \&$ source $=$ web $\& \mathrm{~cd}=2 \&$ ved $=2$ ahUKEwihqKiQx_boAhULQhUIHXeACP0QFjABegQIAhAB \& url $=$ https $\% 3 \mathrm{~A} \% 2 \mathrm{~F} \% 2 \mathrm{Fwww}$.iaisweb.org $\% 2 \mathrm{Ffile} \% 2 \mathrm{~F} 34275 \% 2 \mathrm{Fissues}$-paper-in-regulation-and-
} 
protection as a whole". ${ }^{84}$ It is therefore evident that consumer protection is one of the fundamental principles of effective microinsurance policy implementation. ${ }^{85}$

It is therefore clear that microinsurance is to have profound benefits for low-income earners, essentially offering these consumers access to a product which they never had access to before. The success of microinsurance is based on various factors, especially with regard to a proper and fair regulatory framework. The regulatory framework for any microinsurance products should be aimed at consumer protection.

\subsection{Principles for an Effective Microinsurance Model}

The IAIS highlighted specific principles for the successful implementation of microinsurance in their 2007 policy document. The policy document mentions the following principles as essential for the proper implementation of microinsurance: developing a microinsurance policy and promoting its implementation; facilitating the availability of key information/statistical data on microinsurance business; promoting learning processes and dialogue among relevant sectoral stakeholders; enacting clear laws and regulations in accordance with internationally accepted standard that encourage insurance coverage for low-income households and its compliance while limiting regulatory arbitrage, contributing to the policy dialogue with government so that social insurance schemes are working in conjunction with microinsurance; developing clear policies to enhance access to financial services which can be used as a basis for discussion with legislators, and also between government departments and supervisors; limiting moral hazard and fraud by promoting awareness, and putting in place controls and incentive systems; and promoting consumer education and raising awareness to instill an insurance culture among low-income households. ${ }^{86}$

These principles as highlighted by the IAIS in 2007 are crucial for microinsurance models to succeed. It is now necessary to consider the microinsurance model in South Africa and deliberate exactly what it entails for consumers and the insurance industry as a whole.

supervsion-of-microinsurance-june-2007\&usg=AOvVaw340q6Oe8yb_D9kNa5i0oEp. Accessed 30 August 2019.

${ }^{84}$ Llanto (2007), pp. 61-86.

${ }^{85}$ Llanto (2007), pp. 61-86.

${ }^{86}$ See page 6 of the International Association of Insurance Supervisors and CGAP Working Group on Microinsurance (2007) Issues in Regulation and Supervision of Microinsurance. Available at https://www.google.co.za/url? sa $=t \& r c t=j \& q=\&$ esrc $=s \&$ source $=$ web $\& c d=2 \&$ ved=2ahUKEwihqKiQx_boAhULQhUIHXeACP0QFjABegQIAhAB\&url=https\%3A\%2F\% 2 Fwww.iaisweb.org $\% 2$ Ffile $\% 2$ F34275\%2Fissues-paper-in-regulation-and-supervsion-ofmicroinsurance-june-2007\&usg =AOvVaw340q60e8yb_D9kNa5i0oEp. Accessed 30 August 2019. 


\section{Microinsurance in South Africa}

\subsection{History of Microinsurance}

Microinsurance is a fairly recent concept in the South African insurance industry. ${ }^{87}$ South Africa has always differentiated between indemnity insurance and non-indemnity insurance, long-term insurance and short-term insurance, ${ }^{88}$ and most recently through the enactment of the Insurance Act, ${ }^{89}$ life and non-life insurance. $^{90}$

However, it is evident from the above classifications that microinsurance was never recognised as a formal insurance product. So when did microinsurance first come into the picture? In 2008, the South African National Treasury put forward the idea of microinsurance when it first released a discussion paper on the future of this type of insurance in South Africa for public comment. ${ }^{91}$ This discussion paper was then supported by written-comments and proposals given by participants, which were evaluated and taken into consideration by the Treasury. ${ }^{92}$ In July 2011, after significant consultation, the National Treasury published a policy document on microinsurance ${ }^{93}$ in which a comprehensive policy framework was set out. ${ }^{94}$ The framework emphasised that there were three features of the insurance industry that needed urgent reform; namely, the need to promote better access for South Africans to affordable insurance products that meet the risks they specifically face, the need for consumers to better match the products that they buy with their insurance needs and the strengthening of consumer protection in general. ${ }^{95}$ Financial inclusion for the mass market was the objective of the framework. ${ }^{96}$

This is where the concept of microinsurance was born and thereafter became a formally recognised insurance product with the Insurance Act (IA) ${ }^{97}$ and PPRs

\footnotetext{
${ }^{87}$ Microinsurance was only enacted in 2018 but first received attention back in 2008 when the National Treasury set out a discussion paper on the matter.

${ }^{88}$ Reinecke et al. (2013), p. 10.

${ }^{89} 18$ of 2017.

${ }^{90}$ The Insurance Act defines "life insurance business" as any activity conducted with the purpose of entering into or meeting insurance obligations under a life insurance policy and "non-life insurance business" as any activity conducted with the purpose of entering into or meeting insurance obligations under a non-life insurance policy.

${ }^{91}$ National Treasury (2008) The future of microinsurance regulation in South Africa discussion paper. www.treasury.gov.za, Accessed 13 July 2019. See also Millard (2012), p. 665.

${ }^{92}$ Millard (2012), p. 665.

${ }^{93}$ National Treasury (2011) The South African Microinsurance Regulatory Framework accessed at www.treasury.gov.za. Accessed 13 July 2019.

${ }^{94}$ Millard (2012), p. 665.

${ }^{95}$ National Treasury The South African Microinsurance Regulatory Framework 1. See also Millard (2012), p. 665.

${ }^{96}$ Millard (2012), p. 665.

${ }^{97} 18$ of 2017.
} 
regulating this new type of insurance. The IA defines microinsurance in section 1 as follows:

'microinsurance business' means insurance business:

(a) conducted in respect of any of the following classes and sub-classes of insurance business set out in Schedule 2:

(i) life insurance business, classes 1, 3, 4 or 9; and

(ii) non-life insurance business, in the sub-class personal lines in:

(aa) classes $1,2,3,9,11,14$ or 17 ; and

(bb) class 10 , but only to the extent that the insurance obligations directly relate to the classes referred to in item (aa); and

(b) in the case of life insurance business and class 14 referred to in paragraph (a) (ii) (aa), in respect of which the aggregate value of the insurance obligations relating to each life insured under an insurance policy does not exceed the maximum amounts prescribed; and

(c) in the case of non-life insurance business other than class 14 referred to in paragraph (a) (ii) (aa), in respect of which the aggregate value of the insurance obligations under an insurance policy does not exceed the maximum amounts prescribed; and

(d) in respect of which the aggregate value of the insurance obligations under all insurance policies issued by the same insurer to the same policyholder does not exceed the maximum amounts prescribed under paragraphs (b) and (c).

The Act also defines who a "microinsurer" is and states that it is, "an insurer licensed to conduct only microinsurance business". 98

In the non-life insurance sphere, microinsurance is available in the form of motor, property, agriculture, legal expense, certain liability policies, consumer credit, certain accident and health policies and reinsurance products. ${ }^{99}$ It appears from the above-mentioned forms of microinsurance policies that a lot more consumers will now have access to insurance products that meet their specific needs. This ultimately means that a larger portion of the South African population will now have access to these products. ${ }^{100}$ The 2018 PPRs contain concise rules on this type of insurance product and importantly, sets out the rules on the application of the provisions, ${ }^{101}$ the structure of the policy, ${ }^{102}$ the variation and renewal of such a policy, ${ }^{103}$ waiting

\footnotetext{
${ }^{98}$ See section 1 of the Insurance Act 18 of 2017.

${ }^{99}$ See Table 2: Classes and sub-classes of Insurance Business: Non-life Insurance" in terms of the Insurance Act 18 of 2017. See also Millard (2012), p. 665, 667.

${ }^{100}$ Financial inclusion is paramount to this newly recognised insurance product.

${ }^{101}$ Rule 2A.2.

${ }^{102}$ Rules 2A.4.

${ }^{103}$ Rule 2A.5.
} 
periods, ${ }^{104}$ exclusions, ${ }^{105}$ excesses, ${ }^{106}$ claims, ${ }^{107}$ the reinstatement rules, ${ }^{108}$ and rules on the reporting of a new product. ${ }^{109}$

The insurance market in South Africa is one of the largest on the continent. ${ }^{110}$ The South African insurance market accounted for USD 42 billion of the total premiums written of the global market in 2016. ${ }^{111}$ PWC compiled a report in which they stated that South Africa has the highest insurance penetration levels in Africa and is a relatively more mature market, which might point to fewer opportunities for growth in the future. ${ }^{112}$ However, the increasing growth in premiums tell a different story. Long-term gross written premiums rose from US $\$ 15.8$ bn in June 2016 to US $\$ 19.3$ bn in June 2017, while short-term insurers experienced growth from US\$4.0 bn to US\$4.9 bn over the same period. ${ }^{113}$ This proves that there is major growth on the cards for South Africa and Africa as a whole, especially if the microinsurance market can be tapped. In South Africa, there are also very few big insurers that dominate the market, making entrance for smaller businesses very difficult. $^{114}$

In terms of the microinsurance market in South Africa, the population in the country consists of a vast majority of low-income earners as well as people who are exposed to luxuries such as insurance on a daily basis. ${ }^{115}$ A large part of the population is not considered "financially literate" and this means that many South Africans do not understand financial products and the consequences of these types of products. ${ }^{116}$ This is where microinsurance is to have a significant impact.

\footnotetext{
${ }^{104}$ Rule 2A.6.

${ }^{105}$ Rule 2A.7.

${ }^{106}$ Rule 2A.8.

${ }^{107}$ Rule 2A.9.

${ }^{108}$ Rule 2A.10.

${ }^{109}$ Rule 2A.12.

${ }^{110}$ PWC Report "Ready and Willing: African insurance industry poised for growth" September 2018. Available at https://www.pwc.co.za/en/assets/pdf/south-african-insurance-2018.pdf. Accessed 6 January 2020. This also illustrates why a chapter on South Africa is included in an international European book.

${ }^{111}$ PWC Report "Ready and Willing: African insurance industry poised for growth" September 2018. Available at https://www.pwc.co.za/en/assets/pdf/south-african-insurance-2018.pdf. Accessed 6 January 2020.

${ }^{112}$ PWC Report "Ready and Willing: African insurance industry poised for growth" September 2018. Available at https://www.pwc.co.za/en/assets/pdf/south-african-insurance-2018.pdf. Accessed 6 January 2020. The top four life insurers are very dominant and account for $52 \%$ of the market, while the top non-life players control $56 \%$ of the market.

${ }^{113}$ PWC Report "Ready and Willing: African insurance industry poised for growth" September 2018. Available at https://www.pwc.co.za/en/assets/pdf/south-african-insurance-2018.pdf. Accessed 6 January 2020.

${ }^{114}$ Ibid at page 18.

${ }^{115}$ Mpedi and Millard (2010), p. 508.

${ }^{116}$ Nanziri and Olckers (2019), p. 2.
} 
The financial literacy of South Africans was put to survey by the National Income Dynamics Study and it was found that only $40.57 \%$ of South Africans are financially literate. ${ }^{117}$ It was further found that peoples financial literacy increases when they go on to study a diploma or degree and that household incomes also had an effect on financial literacy. ${ }^{118}$ The survey found that $63.3 \%$ of households with an income of R30,000 or more per month are financially literate compared to only $34.1 \%$ in households of R5000 per month or less. ${ }^{119}$ This proves that low-income earners, the possible microinsurance consumer, is not always financially literate and therefore, there is a need that these products are designed correctly for these specific consumers.

A further study conducted by the Financial Services Board in 2015 showed that about $69 \%$ of adult South Africans do not have emergency funds to cover their expenses for 3 months in case of sickness, job loss, economic downturn or other emergency. ${ }^{120}$ When surveying people about insurance products the study revealed that only $38 \%$ percent of South Africans indicated that they do not hold at least one insurance product in 2015 compared to $62 \%$ of adults who hold at least one insurance product. ${ }^{121}$ Only $51 \%$ of South African adults are aware of insurance products. $^{122}$ The most popular type of insurance product held was funeral insurance with $28 \%$ of adults holding an account with a burial society. ${ }^{123}$

From the above it is therefore apparent that there is a need for microinsurance products for low-income earners in South Africa. These consumers also require protection from risks but it is essential that microinsurance products are designed and sold differently to these consumers in order to cater for their needs.

\subsection{Policyholder Protection Rules on Microinsurance}

\subsubsection{Introduction}

Microinsurance is now recognised as a formal type of insurance product in South Africa. ${ }^{124}$ Since the promulgation of the Insurance Act, ${ }^{125}$ microinsurance is regulated by statute and the specific rules on how these products are to be structured

\footnotetext{
${ }^{117}$ Nanziri and Olckers (2019), p. 2.

${ }^{118}$ Nanziri and Olckers (2019), p. 2.

${ }^{119}$ Nanziri and Olckers (2019), p. 2.

${ }^{120}$ Roberts et al. (2016), p. 9.

${ }^{121}$ Roberts et al. (2016), p. 9.

${ }^{122}$ Roberts et al. (2016), p. 9.

${ }^{123}$ Roberts et al. (2016), p. 9.

${ }^{124}$ See the Insurance Act 18 of 2017 as well as the 2018 PPRs.

${ }^{125} 18$ of 2017 .
} 
and carried out are outlined in the PPRs. ${ }^{126}$ Chapter 3 of the 2018 PPRs regulates microinsurance. Rule $2 \mathrm{~A}$ has been included and the rule regulates various aspects of microinsurance. ${ }^{127}$ These rules are to have a profound impact on low-income earners and households.

The PPRs have set stringent rules as to how these types of policies may be designed, marketed ${ }^{128}$ and sold to low-income earners in South Africa. In addition, all non-life insurance products are regulated by the 2018 PPRs which also include rules on product design as well as disclosure requirements. ${ }^{129}$

\subsubsection{Specific Rules on Microinsurance}

\subsubsection{Outline}

Rule 2A of the 2018 PPRs contains comprehensive guidelines on all aspects of microinsurance. ${ }^{130}$ These rules will be dealt with in further detail below. Rule 2A.2 starts off with setting out the application of the rule and states that,

This rule applies to any microinsurance policy and applies concurrently with, and in addition to, all other rules set out in these Policyholder Protection Rules. If there is an inconsistency between any provision of this rule and any other rule in these Policyholder Protection Rules, the provision of this rule prevails.

In terms of the use of the term 'microinsurance' rule 2A.3 states that, "An insurer, other than a microinsurer, or any person acting on behalf of that insurer may not use the term 'microinsurance' or any derivative thereof in respect of a policy or in any advertisement in respect of a policy."

\subsubsection{Structure of the Policy}

The structure of a microinsurance policy is significant as it is important to note exactly how these types of products are designed with the specific consumer in mind. Rule 2A.4 states that a microinsurance policy may not have a contract term of more than 12 months and also that the value of the policy benefits under a microinsurance policy may not exceed the maximum amounts as prescribed by the Prudential Authority. The rule also makes mention of the fact that such a policy must, upon expiry of its contract term, either be automatically renewed; or terminated in

\footnotetext{
${ }^{126}$ See rule $2 \mathrm{~A}$ in terms of the Short-term Insurance Act Policyholder Protection Rules.

${ }^{127}$ Including claims, excesses, reporting of new products and the structure of these policies.

${ }^{128}$ Rule 10 sets out the rules for the advertising of insurance products.

${ }^{129}$ Rule 2 and rule 11 respectively.

${ }^{130}$ Every aspect from the structure of the policy, to waiting periods, to exclusions is dealt with in rule $2 \mathrm{~A}$.
} 
accordance with the requirements set out in these Rules. ${ }^{131}$ A microinsurance policy may not provide that any of the policy benefits thereunder is subject to the principle of average. $^{132}$

Therefore, microinsurance policies may not have a contract term more than 12 months and the monetary cap introduced under the section gives effect to the very basic principle of microinsurance: that is that the value of the policy should not exceed a specific amount. ${ }^{133}$ The fact that a microinsurance policy is valid for a 12-month period does not appear to be any different from other short-term insurance contracts, as most short-term policies are valid for a period of 12 months and are then renewable after that period has expired. ${ }^{134}$

\subsubsection{Waiting Periods}

A waiting period is for the most part a regular feature in insurance contracts. These periods usually provide for a time period which has to elapse before a benefit will be paid to the policyholder. ${ }^{135}$

As far as waiting periods for microinsurance policies are concerned, rule 2A.6 states that, "a microinsurance policy, underwritten under the accident and health class of non-life insurance business as set out in Table 2 of Schedule 2 to the Insurance Act, may not impose a waiting period exceeding the shorter of one quarter of the term of the policy or 6 months, in respect of which policy benefits are payable on the happening of a death, disability or health event resulting from natural causes". ${ }^{136}$ Additionally, a microinsurance policy may also not impose a waiting period in respect of policy benefits payable on the happening of a death, disability or health event resulting from an accident. ${ }^{137}$ Furthermore, a microinsurance policy may also not impose a waiting period when it is renewed.

\footnotetext{
${ }^{131}$ Rule 2A.4.3.

${ }^{132}$ See rule 2A.4.1.-2A.4.4.

${ }^{133}$ Caps under microinsurance policies are limited to R100,000 for life insurance and R300,000 for non-life insurance. See also Millard (2012), p. 665, 667.

${ }^{134}$ Millard (2012), p. 665, 667. As far as the variation and renewal of a microinsurance policy goes, rule 2A.5.1 states that the terms, conditions or provisions of a microinsurance policy may not be changed or varied during the first 12 months after inception of the policy, unless the microinsurer can demonstrate that there are reasonable actuarial grounds to change or vary the terms, conditions or provisions of the microinsurance policy or that the variation will be to the benefit of the policyholder or member of a group scheme concerned; and the variation is done in accordance with rules 11.6.3 and 11.6.4.

${ }^{135}$ Millard (2012), p. 665, 668.

${ }^{136}$ Rule 2A.6.1.

${ }^{137}$ Rule 2A.6.2.
} 


\subsubsection{Exclusions}

Exclusion clauses are another common feature in insurance policies. Exclusion clauses generally provide that the liability of the insurer will be excluded in specific instances. ${ }^{138}$ The policyholder should be aware of any exclusion clauses as contained in the policy as these clauses directly affect the liability of both parties to the contract. ${ }^{139}$ Policyholders should be aware of instances where the insurer will not cover them. This is generally in line with consumer protection provisions. As far as microinsurance policies are concerned, rule 2A.7.1. states that a microinsurance policy in respect of which the aggregate value of the policy benefits is R120,000 or less may not impose any exclusions or conditions limiting the liability of the microinsurer, other than exclusions or conditions relating to:

(a) unlawful conduct, provided that such exclusions may only be applied or relied on if there is a direct link between the cause of the loss and the unlawful conduct;

(b) special risks referred to in the Conversion of the SASRIA Act, 1998 (Act 134 of 1998);

(c) the condition of any asset insured at inception of the policy, other than exclusions relating to the wear and tear of the asset;

(d) the maintenance and usage of the insured asset under a policy that insures against unforeseen mechanical or electrical component failure;

(e) consequential loss; or

(f) any combination of (a) to (e).

From the above it is evident that the exclusion rules relating to microinsurance policies ensure that exclusions in these policies are limited to specific instances of unlawful conduct and general unlawfulness.

Rule 2A.7.2 then provides that a microinsurance policy in respect of which the aggregate value of the policy benefits exceeds R120,000 may impose exclusions or conditions, in addition to those set out in rule 2A.7.1(a) to (f), limiting the liability of the microinsurer if the microinsurer is able to demonstrate that such exclusions or conditions will:

(a) not unreasonably erode the value of the benefits under the policy, taking into account the nature of the policy benefits;

(b) continue to render the policy being suitable for targeted policyholders; and

(c) not compromise the consistent delivery of fair outcomes to the policyholders or members.

Once again, reaching an equitable balance between the insurer and policyholder appears to be the aim of the provision.

\footnotetext{
${ }^{138}$ Reinecke et al. (2013), pp. 241 and 112 state that parties to an insurance contract should be in agreement on the identities of the parties to the contract the performances to be rendered by each of them. In addition, the authors state that "[c]onsensus about performance requires unanimity about the existence and meaning of the proposed terms of the contract, such as warranties, suspensive and resolutive conditions, exclusions, time clauses and any other terms affecting the parties' respective obligations."

${ }^{139}$ Reinecke et al. (2013), pp. 241-242. See also Millard (2012), pp. 668-669.
} 


\subsubsection{Excesses}

An excess clause provides that a policyholder must bear the first portion of the loss himself. ${ }^{140}$ In principle, this means that a policyholder will only be able to claim if the loss suffered is more than the excess required to be paid in terms of the policy. ${ }^{141}$ In terms of microinsurance, such policies should contain an excess that is proportionate to the loss suffered. In terms of rule $2 \mathrm{~A} .8 .1$, it is mentioned that microinsurance policies may only provide one standard excess per risk event covered under a particular class of non-life insurance business. ${ }^{142}$

Additionally, rule 2A.8.2 specifies that if an excess is payable under a microinsurance policy, such excess must be disclosed to a policyholder or member of a group scheme, or a potential policyholder or potential member of a group scheme in accordance with rules $11.4 .1,11.5 .1^{143}$ and 17.10. Therefore, excess payments must be disclosed to the prospective policyholder before the contract is entered into. The PPRs further regulate the disclosure of excess payments. ${ }^{144}$ The fact that excesses must be disclosed to microinsurance policyholders is indispensable to these policyholders as they do not always have the finances readily available at any given time.

Excess amounts should be proportional to the loss suffered ${ }^{145}$ and rule 2 A.8.3 states that where any excess is payable under a microinsurance policy in respect of which the aggregate value of the policy benefits is R120,000 or less, the excess may not exceed the lower of $10 \%$ of the value of the policy benefits, payable for the risk event as set out in the policy ${ }^{146}$ or R1000. ${ }^{147}$ Where the aggregate value of the policy benefits exceeds R120,000, the excess payment may not exceed $10 \%$ of the value of the policy benefits, payable for the risk event as set out in the policy. An additional

\footnotetext{
${ }^{140}$ Reinecke et al. (2013), pp. 327-328 and 242.

${ }^{141}$ Ibid.

${ }^{142}$ Rule 2A.8.1. As referred to in Table 2 of Schedule 2 of the Insurance Act.

${ }^{143}$ These rules regulate pre-contractual disclosure of all contractual terms, including excess payments.

${ }^{144}$ Rule 17.10 provides that "Where any excess is payable by the policyholder, the excess:

(a) must be clearly disclosed to the policyholder as required by rules 11.4.2(d)(iii) and 11.5.1(c) (iii);

(b) must be disclosed to the claimant as required by rule 17.8.3;

(c) must be fair and reasonable; and

(d) may not constitute an unreasonable barrier to a claimant, taking into account the reasonably assumed circumstances and expectations of the average targeted policyholder and claimant in respect of the policy concerned."

${ }^{145}$ Reinecke et al. (2013), pp. 327-328.

${ }^{146}$ Rule 2A.8.3(a).

${ }^{147}$ Rule 2A.8.3(b).
} 
requirement in the new rules provides for an annual inflation-linked escalation of these values. $^{148}$

In light of the above provisions it appears as if the rules on excess amounts for microinsurance policies are very much in line with the purpose of microinsurance, in that the aimed target market are given value for money, especially where the amount of money these consumers have, is the key consideration.

\subsubsection{Claims Process}

Claims stage is a critical period in the insurance relationship. ${ }^{149}$ Usually policyholders only become aware of certain contractual provisions which may impact them negatively at this stage. ${ }^{150}$

In terms of microinsurance policies, rule 2A.9.1 states that subject to rule 2A.9.2, a microinsurer must, within 2 business days after all required documents in respect of a claim under a microinsurance policy have been received, assess and make a decision whether or not the claim submitted is valid, ${ }^{151}$ and authorise payment of the claim, ${ }^{152}$ repudiate the claim, ${ }^{153}$ or dispute the claim and notify the insured of any dispute. ${ }^{154}$

In the case where an insurer disputes a claim submitted by the policyholder, the insurer must, within 14 business days after expiry of the period referred to in rule 2A.9.1 investigate the claim further, ${ }^{155}$ come to a decision whether the claim submitted is in fact valid, ${ }^{156}$ and then make a decision as to whether to pay or repudiate the claim. ${ }^{157}$ It must be kept in mind that these types of policyholders do not have the additional resources lying around to simply cover a loss and therefore they are strongly relying on the insurance coverage taken out. Insurers should therefore comply with the short time-frames in order to compensate the policyholder efficiently and effectively.

A noteworthy provision in the rules comes out in rule 2A.9.3. This rule stipulates that a microinsurer may not reject a claim under a microinsurance policy on the basis

\footnotetext{
${ }^{148}$ Rule 2A.8.5. The amounts referred to in this rule escalates annually, from the effective date of this rule, by the Consumer Price Index (CPI) annual inflation rate published by Statistics South Africa, as defined in section 1 of the Statistics Act, 1999 (Act 6 of 1999).

${ }^{149}$ Reinecke et al. (2013), p. 320.

${ }^{150}$ Reinecke et al. (2013), p. 322. For example, forfeiture clauses generally only come to the knowledge of the policyholder when they submit a claim at claims stage.

${ }^{151}$ Rule 2A.9.1(a).

${ }^{152}$ Rule 2A.9.1(b)(i).

${ }^{153}$ Rule 2A.9.1(b)(ii).

${ }^{154}$ Rule 2A.9.1(b)(iii).

${ }^{155}$ Rule 2A.9.2(a).

${ }^{156}$ Rule 2A.9.2(b).

${ }^{157}$ Rule 2A.9.2(c).
} 
that the policyholder did not disclose if the microinsurer did not specifically request the policyholder to disclose that information before the inception of the policy. This is to have far-reaching consequences for microinsurance policyholders. Evidently, insurers now have to play a more active role in the pre-contractual disclosure phase and must ask the necessary questions. ${ }^{158}$ Therefore, disclosure requirements for non-life microinsurance products are very much pro-consumer and seek to protect the consumers in a real manner. Obviously, rule 2A.9 will be a game changer for the consumer in protecting their rights at claim stage.

\subsubsection{Reinstatement}

The concept of reinstatement of insurance policies occurs when a policy has lapsed due to the non-payment of the premium within the days of grace. ${ }^{159}$ The payment of premiums is always a cause for concern in insurance policies. Where an insurer reinstates a policy, reinstatement is in effect a renewal of the contract on the same terms as before and insurers may specify formalities before considering the reinstatement of a lapsed policy. ${ }^{160}$

In terms of microinsurance policies, rules 2A.10.1(a) and (b) stipulate that if a microinsurance policy has lapsed due to the non-payment of premium and the microinsurer reinstates such policy, the microinsurer must do so on at least the same terms as the policy that had lapsed and may not impose a waiting period under the reinstated policy. Additionally, rule 2A.10.2 stipulates that if a microinsurer enters into a new microinsurance policy with the same policyholder or member of a group scheme within 2 months after a microinsurance policy has lapsed due to the non-payment of premium, the microinsurer may not impose a waiting period under such new policy. ${ }^{161}$

Therefore, the rules on reinstatement of policies are very much pro-consumer and afford the policyholder a fair amount of protection.

Now that the concept of microinsurance on an international level as well as in terms of South African law has been considered, it is necessary to now focus on the provisions of product design in South Africa. The IDD highlights the importance of product design in insurance products as well as the sales side of these products. The evaluation of the provisions of the IDD above illustrated the importance of taking customers' needs into consideration and product approval processes. ${ }^{162}$ Interestingly

\footnotetext{
${ }^{158}$ This appears to be in line with the recent decision in Mahadeo v Dial Direct Insurance Ltd 2008 4 SA $80(\mathrm{~W})$.

${ }^{159}$ Reinecke et al. (2013), p. 105.

${ }^{160}$ Reinecke et al. (2013), p. 105.

${ }^{161}$ Rule 2A.10.3 stipulates that rule 2A.10.2 does not apply where the policyholder or member of a group scheme had not completed a waiting period imposed under the lapsed policy, in which case the microinsurer may impose a waiting period not exceeding the unexpired part of the waiting period under the lapsed policy.

${ }^{162}$ See paragraph 2 above.
} 
enough, South Africa has included concise rules on product design in the PPRs. These rules also demonstrate the importance of both approval processes and consumer needs. Therefore, these rules will be evaluated below and once these rules have been clarified, the question of whether South Africa can learn or take away anything of value from the IDD provisions, will be deliberated.

\subsection{Policyholder Protection Rules on Product Design}

Rule 2 in the 2018 PPRs deals with the product design of various insurance products. ${ }^{163}$ In terms of non-life insurance products, rule 2 places specific rules and restrictions on insurers when developing these products. The rule starts off by stating that insurers when developing products must make use of adequate information on the needs of identified types, kinds or categories of policyholders or members; ${ }^{164}$ insurers must undertake a thorough assessment, by competent persons with the necessary skills, of the main characteristics of a new product, the distribution methods intended to be used in relation to the product and the disclosure documents related thereto in order to ensure that the product, distribution methods and disclosure documents ${ }^{165}$ :

(i) are consistent with the insurer's strategic objectives, business model and risk management approach and applicable rules and regulations;

(ii) target the types, kinds or categories of policyholders or members for whose needs the product is likely to be appropriate, while mitigating the risk of the product being used by types, kinds or categories of policyholders or members for whom it is likely to be inappropriate; and

(iii) take into account the fair treatment of customers; and insurers that are subject to white labelling arrangements, must undertake due diligence in the assessment in respect of the governance, resources and operational capability of the persons with whom the insurer has such arrangements and ensure compliance with paragraph (b) above. ${ }^{166}$

Rule 2.2 goes further and states that "before an insurer starts to market, offer or enter into specific policies in respect of a new product, a senior manager of the insurer must in writing approve the product and confirm that the product, distribution methods and disclosure documents meet the principles set out in rule 2.1(b)."167

\footnotetext{
${ }^{163}$ These rules thus apply to all non-life insurance products including microinsurance products.

${ }^{164}$ Rule 2.1. (a).

${ }^{165}$ Rule 2.1. (b).

${ }^{166}$ Rule 2.1. (c).

${ }^{167}$ See rule 2.2. Also, take note that rule 2.3 . states that 2.3 this rule only applies to the development of any new product as of 1 January 2018 and any material change in design of an existing product."
} 
In summary, it is evident that the rules on product design as set out in the 2018 PPRs are strongly geared towards making sure that various non-life insurance products are designed with the correct consumer in mind. Insurers can no longer design insurance products for a broad market. Rather, they now need to make sure that they can identify the needs of various types of consumers and design insurance products with these specific consumer needs in mind. They also need to do appropriate research on their consumers, identify various distribution channels to be used when marketing the specific products to the consumers as well as always ensuring the customers are treated fairly throughout the entire process. ${ }^{168}$

It is thus clear that rule 2 also identifies the various distribution channels through which products may be marketed to consumers and also takes into account the disclosure requirements for consumers. ${ }^{169}$ This is similar to what the IDD sets out in its provisions and rules. The IDD focuses strongly on making sure that consumers are treated equally in the designing and marketing of insurance products, despite the different distribution channels used by insurers. ${ }^{170}$

Therefore, rule 2 in the 2018 PPRs encompasses many of the same principles as in the IDD, in that insurance products should be designed with a specific market in mind as well as the fact that the product should be marketed to the correct market and that customers are treated fairly throughout the entire process. This means that in the realm of microinsurance, these now formalised insurance products must be designed for low-income consumers and should be specifically geared towards them.

\subsection{Disclosure Requirements in Terms of the PPRS}

Rule 11 of the 2018 PPRs provides for certain disclosure requirements, similar to what we see in the IDD. In terms of rule 11.3.1, it is required that insurers provide communication to policyholders in plain language, which must not be misleading, in an appropriate medium, clear and readable print sizing and monetary amounts must be provided in monetary terms.

Further, rule 11.3.2. states that an insurer must take reasonable steps to ensure that a policyholder is given appropriate information about a policy in good time so that the policyholder can make an informed decision about the policy prior to inception and throughout the duration of the policy. ${ }^{171}$

\footnotetext{
${ }^{168}$ See rule 2.3 .

${ }^{169}$ Take note that rule 11.3.2. specifically states that policyholders must be given appropriate information about a policy in good time so that the policyholder can make an informed decision about the policy prior to inception and throughout the policy.

${ }^{170}$ See paragraph 2.2 . above.

${ }^{171}$ This applies to intermediaries too in terms of rule 11.3.6 and 11.3.7. What is considered good time will depend on the importance of the information in the policyholder's decision making process and the point at which it is considered most useful. See further rule 11.3.4.
} 
Also of significance is rule 11.4.1(a) which states that where the insurer provides a policyholder, or intermediary, before a policy is entered into, with a policy quotation or similar communication that purports to provide detailed information to the policyholder, and it may be reasonably expected that the policyholder will rely on such information to make a decision whether to enter into the policy or not, the quotation or communication must include information as set out in rule 11.4.2. ${ }^{172}$

Interestingly, this rule puts the burden on both the insurer as well as an intermediary. Therefore, insurers must give the intermediaries the information and then it can be expected that the intermediaries must relay this information to the consumer. It must be noted that intermediaries are governed by the Financial Advisory and Intermediary Services Act ${ }^{173}$ and FAIS requires intermediaries to also disclose relevant information to the consumer before the contract is concluded in terms of the General Code of Conduct. ${ }^{174}$

This is similar to the disclosure requirements as set out in the IDD, however, one noticeable difference is that the IDD makes specific mention of the length of this document which can be vital to microinsurance consumers who may benefit from a short-concise document outlining the important aspects of the policy.

Evaluation of the product design and disclosure requirements for microinsurance products.

If we apply the provisions of product design in the PPRs specifically to microinsurance products, then it is safe to say that non-life microinsurance products must be designed by insurers in a way that takes into account exactly what these consumers require from such products, that insurers identify exactly who their market is and what they need from insurance products and then design the products accordingly. ${ }^{175}$

Insurers must also consider the exact distribution channels of microinsurance products in order to ensure that the correct market is identified and that the best distribution channels for these consumers are utilised. It is also essential that insurers design microinsurance products in a manner that promotes the fair treatment of these customers at all times. ${ }^{176}$ In addition, it is crucial that a senior manager approves the microinsurance product before it is specifically marketed or offered to the

\footnotetext{
${ }^{172}$ This rule states that the insurer must provide the policyholder with the name of the insurer, type of policy, nature and extent of policy benefits, any charges or fees levied against the policy, premium payable, frequency of premium, cooling-off rights, exclusions or limitations and any circumstance which could give rise to a conflict of interest.

${ }^{173} 37$ of 2002 .

${ }^{174}$ See section 3(1) of the GCC which requires that providers must, when rendering a financial service such as giving advice, must ensure that such advice is factually correct, provided in a plain language, given timeously so as to allow the consumer to make an informed decision, must be adequate and appropriate for the consumer taking into account their level of knowledge, must be provided in writing if so requested by the consumer etc.

${ }^{175}$ Rule 2.1.

${ }^{176}$ Rule 2.
} 
consumers. ${ }^{177}$ The role of the senior manager in this instance is to confirm that the product, its distribution channels and disclosure of all necessary documents meet the principles of rule 2.1(b). Therefore, there is an approval process in place, similar to what we see in article 25 of the IDD.

The provisions on microinsurance specifically appear to be pro-consumer and aim to protect the consumers in almost every aspect. Although some of the provisions in rule $2 \mathrm{~A}$ are quite similar to other short-term (non-life) policies, such as the time period of 12 months or the waiting period provisions, it is still evident that the rules are strongly based on the protection of the consumer. From the product design stage of microinsurance policies, to the advertising and selling of these products, all the way to claims management procedures, the PPRs apply and therefore, consumer protection is the idea throughout. Therefore, microinsurance consumers will also receive the benefits of disclosure as set out in rule 11, ensuring that they receive adequate information before the inception of the policy in order to make an informed decision.

However, is this sufficient in protecting the needs of microinsurance consumers? Is there not more that can be done to personalise these products for the consumer? This is where the IDD comes in. The following paragraph will ask the ultimate question of, what can South Africa learn or take away from the IDD?

\section{What Can South Africa Take Away from the IDD to Enhance the Current Microinsurance Provisions?}

The IDD is a comprehensive piece of legislation. The directive is specifically aimed at providing uniform rules on product design and the sales of insurance products across various distributors. The emphasis and inclusion of various distributors is significant as this is broadening the application of the directive to more products and providers. Therefore, creating a fairer insurance market for all customers. The analysis of the directive above highlighted the most significant aspects of the directive. It is evident that the customer comes first and that insurance products are designed specifically taking into account the interests and needs of a target market. The distributors of the insurance products must then ascertain if a single customer falls within the target market of the specific product. If they do fall within the target market, then distributors can adapt the product based on the customer's needs. This therefore ensures that the customer is in fact receiving a product which takes their personal needs into account. This is a commendable feature of the directive. No longer can insurers sell one single product for every customer. Rather, products must be designed according to the target market, which is selected by insurers in accordance to the customer's needs. This is to have far-reaching benefits for the customer. The fact that the directive also encompasses more distributors who must comply

${ }^{177}$ Rule 2.2. 
with the directive ensures that customers are receiving the same and fair treatment across all suppliers and distributors. Therefore, customers do not need to worry that because they are dealing with an intermediary, and not directly with an insurer, that they might not be receiving the same advice or treatment. This ensures fairness on all levels of distribution.

One of the most significant features of the directive is the product information document that customers must receive before the contract is concluded. The fact that customers must receive a document that is short, concise, not misleading, accurate, in an official language and which explains to the customer what the product entails, is in fact the most far-reaching provision of the directive. This document allows consumers, at the pre-contractual stage, to make an informed decision. It appears as if this specific provision can be of most value to the South African microinsurance model. Although the PPRs have rule 11.3 and 11.4 which deal with disclosures at the pre-contractual stage, the IDD is far more specific in the fact that it must be a two (2) page document and that it must be in an official language. These two factors can have a significant impact on potential microinsurance consumers.

It was stated above that the vast majority of the population in South Africa are not financially literate and are low-income earners. Thus, making microinsurance a viable option for many people. However, we also face the barrier of most of these consumers not speaking or understanding the English language. South Africa has 11 official languages and therefore, the majority of the population do not speak or understand English. It is trite that insurance policies in South Africa are generally stipulated in English. This will prove to be a major obstacle to the microinsurance consumer. Therefore, South Africa would benefit from following this provision of the directive aimed at providing product information documents that are concise and in an official language.

If South Africa were to follow this approach as adopted in the IDD then that would mean that microinsurance consumers should receive a specific document which is short, concise, not misleading, in plain language, in one of the official languages of the country, and which clearly sets out what the policy entails and what insurance product the consumer is covered for. This would have extensive benefits for the consumer. By receiving a document that is easy to understand, that is in a language they speak and that is short and concise, this can reduce the uncertainties and issues that come about through long-winded policies which are difficult for the layman to understand.

This is a crucial feature which can enhance consumer protection in the microinsurance sphere. It is evident that the current PPRs are very much on track with the IDD in terms of product design, disclosure requirements and the fact that products must be designed with consumers needs in mind. South Africa also follows a similar process of product approval for insurance products. The PPRs currently state that insurance products must go through an approval process by a senior manager who will ensure that the products have been correctly designed for a specific consumer and that their needs were taken into account. However, we do not see a similar provision in the PPRs to that of the product information document 
as contained in the IDD with regards to the length of the document and the language requirement.

Therefore, if we come back to the question of this chapter which asked, what can the IDD offer the South African microinsurance market? It then becomes clear that following the provisions as set out in article 20 will provide microinsurance consumers in South Africa with significant protection. Article 20(4) also specifically makes mention of the "type of customer", this is something that the PPRs should also make mention of. It needs to be remembered that all customers are different, therefore we cannot apply the same selling and advice standards to all customers. Products should be sold differently according to the type of customer.

Article 20(6) state that for non-life insurance products, the information referred to in paragraph 4 shall be provided by way of a standardised insurance product information document. Paragraph 7 then sets out what the document should entail. Paragraph 8 goes even further by stating exactly what kind of information the document should encompass. It states that it should contain information about the type of insurance, the cover provided, the main risks (included and excluded), premiums and duration of payments, obligations on terms of the contract, what happens when a claim is made, the duration of the contract and terminating the contract.

Although South Africa has similar provisions in rule 11.3.2. and rule 11.4.2 of the PPRs, it would have more of an impact on consumers to have a very short document, being restricted to 2 pages, and in an official language of the consumer. The two rules are also currently applicable to intermediaries too and therefore, the obligation will extend to intermediaries to provide consumers with a standardised insurance product document, as in line with the current rules 11.3.6 and 11.4.1. of the PPRs, as well as in terms of the FAIS General Code of Conduct.

The benefit of providing a standardised insurance product information document to the microinsurance consumer should outweigh the cost of having to prepare such a document. As far as the cost implication goes for the insurer in developing the standardised insurance product information document for the consumer, it is submitted that there will not be any major financial burden on the insurer in developing this document. Currently, rule 11.4.1. of the PPRs allows for insurers to supply policyholders with a quotation or similar communication before the policy is entered into which enables the policyholder to make an informed decision, and this does not come with any additional cost to the policyholder. Rule 11.4.2. sets out the information which must be contained in this quotation or communication and the list is extensive. Once again, no mention of fees to the policyholder is made mention of. Insurers provide this information free of charge to consumers. Therefore, it is submitted that producing a standardised insurance product information document for microinsurance consumers will not cause a financial burden and will only assist the consumers in making an informed decision as to whether to enter into the policy or not. Providing the document in an official language should not affect the consumer 
as in terms of the National Credit Act ${ }^{178}$ section 63 states that every consumer has the right to receive documents in an official language to the extent that it is reasonable having regard to usage, practicality, expense, regional circumstances and the balance of the needs of the population. Section 65(3) of the Act then goes on to state that a credit provider must not charge a fee for the original copy of any document required to be delivered to a consumer in terms of this Act. Therefore, the NCA makes it clear that documents may be requested in an official language and that the provider may not charge a fee for such documents. If we apply this to another financial sector, the insurance industry, then it is not irrational to assume that insurers are to provide consumers with an information document at the pre-contractual stage in an official language at no cost to the consumer. Rather, insurers should focus on this vast untapped market that is capable of bringing in significant revenue for the insurer.

\section{Conclusion}

The product design of insurance products is no longer an easy or effortless task for insurers. Insurers used to be in control of the process of product design and they were previously the ones who could set the tone of how various types of insurance products were designed and marketed to the public. This is no longer the case. The IDD, in the EU market, and the PPRs in terms of South African legislation, are both setting clear and concise rules on exactly how various insurance products are to be designed and marketed to the public. Consumer protection is at the forefront of both of these pieces of legislation. Insurers and intermediaries must now follow strict rules when designing and marketing insurance products. The fact that the EU as well as South Africa have recognised the importance of protecting consumers, at various phases of any insurance product lifecycle, is commendable.

With specific regard to microinsurance products, this means that these more vulnerable consumers are now afforded additional protection in the design of these specific insurance products. Microinsurance policyholders can now be guaranteed that the policies are designed with their specific needs accounted for. However, there is more that can be done in the sales of these products to protect consumers. By following the IDD in terms of its momentous provision of the insurance product information document, South Africa can ensure better and more personalised protection for microinsurance consumers. South Africa should provide a similar document for its microinsurance consumers and the PPRs should make mention of taking into account the type of customer purchasing the product.

It is pertinent to remember that not all customers are the same and therefore it is necessary to take different types of customers' needs into account. The South African microinsurance model can only benefit from taking the provisions

${ }^{178} 34$ of 2005 . 
of article 20 of the IDD into account when selling microinsurance products. This will ensure a higher level of consumer protection as a whole for consumers which have for the most art been excluded from the insurance industry for all this time.

\section{References}

\section{Articles, Documents and Textbooks}

Biener C, Eling M, Schmit J (2013) Regulation in microinsurance markets: principles, practice, and directions for future development. Working Papers on Risk Management and Insurance No 127

Churchill C, Matul M (eds) (2007) Protecting the poor: a microinsurance compendium, vol II. International Labour Organization, Geneva

Hunt J (2019) What is Microinsurance? The Balance https://www.thebalance.com/what-ismicroinsurance-4165961

ILO (2012) Microinsurance coverage expanding at breathtaking pace according to ILO and the Munich Re Foundation. ILO Press Release, ILO, Geneva, Switzerland

International Association of Insurance Supervisors and CGAP Working Group on Microinsurance (2007) Issues in Regulation and Supervision of Microinsurance. Available at https://www. google.co.za/url? $\mathrm{sa}=\mathrm{t} \& \mathrm{rct}=\mathrm{j} \& \mathrm{q}=\& \mathrm{esrc}=\mathrm{s} \&$ source $=$ web\&cd $=2 \& \mathrm{ved}=2 \mathrm{ahUKEwihqKiQx}$ boAhULQhUIHXeACP0QFjABegQIAhAB\&url=https\%3A\%2F\%2Fwww.iaisweb.org\% 2Ffile $\% 2 \mathrm{~F} 34275 \% 2$ Fissues-paper-in-regulation-and-supervsion-of-microinsurance-june2007\&usg=AOvVaw340q6Oe8yb_D9kNa5i0oEp. Accessed 30 Aug 2019

Llanto G (2007) Policy and regulatory issues and challenges in microinsurance: a Philippine case. Philipp J Dev 34(1):61

Millard D (2012) Harnessing the informal economy: some reflections on National Treasury's Policy Document on the South African Microinsurance Regulatory Framework. THRHR 665

Mpedi L, Millard D (2010) Bridging the Gap: the role of microinsurance in a comprehensive social protection system in South Africa. Obiter 508

Nanziri LW, Olckers M (2019) Financial literacy in South Africa (2019) 2. (SALDRU Working Paper Number 242 Version 1/NIDS Discussion Paper 2019/9)

PWC Report "Ready and Willing: African insurance industry poised for growth" September 2018. Available at https://www.pwc.co.za/en/assets/pdf/south-african-insurance-2018.pdf

Reinecke MFB, van Niekerk JP, Nienaber PM (2013) South African insurance law. LexisNexis, South Africa, p 10

Roberts B, Struwig J, Gordan S (2016) Financial literacy in South Africa: results from the 2015. S Afr Soc Attitudes Surv, 9

\section{Legislation}

Financial Advisory and Intermediary Services Act 37 of 2002

Insurance Act 18 of 2017

Insurance Distribution Directive (EU) 2016/97

National Credit Act 34 of 2005

Policyholder Protection Rules 2018 
Open Access This chapter is licensed under the terms of the Creative Commons Attribution 4.0 International License (http://creativecommons.org/licenses/by/4.0/), which permits use, sharing, adaptation, distribution and reproduction in any medium or format, as long as you give appropriate credit to the original author(s) and the source, provide a link to the Creative Commons licence and indicate if changes were made.

The images or other third party material in this chapter are included in the chapter's Creative Commons licence, unless indicated otherwise in a credit line to the material. If material is not included in the chapter's Creative Commons licence and your intended use is not permitted by statutory regulation or exceeds the permitted use, you will need to obtain permission directly from the copyright holder. 